\title{
DIE LOOP VAN DIE DINGE.
}

\author{
(L. J. DU Plessis.)
}

'Terwyl dic Spaanse burgeroorlog haas beslis is ten gunsle van die Fasjiste, het Frankryk en die res van Europa behalwe Duitsland eindelik ook die sterling-voorbeeld van wisselende devaluasie aanvaar. llierby sal Amerika-Fingeland-Frankryk in samewerking 'n sekere stabiliteit probeer handhaaf en miskien ook die weg aanwys tot definitiewe stabilisasie van die wisselkoers. Maar die gevaar vir inflasie is groot, veral wat Frankryk betref, en daarmec ook die gevaar van rewolusic. Selfs in die ordentlike Engeland is reeds opbruisinge merkbaar van fasjistiese reorganisasiesug. Allerweë word teen die dreigende internasionale en binnelandse gevare afwcer gesock in stabilisasicooreenkomste ook ten opsigte van grense en bewapening. Maar in hoever hierin die kant meer gekies word van Duitsland of van Rusland is nog nie heeltemal duidelik nic. In elk geval skyn dit of die Volkebond laamlik wel op die agtergrond bly, nieteenstaande die sensasie veroorsaak deur die toclating van Abessinië tot die vergadering.

Intussen druk Japan vinnig deur met sy vreedsame verowering van Sjina. Die vermaninge van Amerika en Engeland laat wel soms 'n tydelike stilstand intree, maar na 'n tydjie begin die indringing weer van mults af en inderdaad skyn dit of die verowering al byna voltooi is, terwyl Amerika besig gehou word deur sy binnelandse onsekerheid en Engeland se aandag in Europa en Palestina in beslag geneem is.

In 1936, die jaar waarin Europa die vierde ecufees gevier het van twee grool eenheidsapostels : die humanis Desiderius lirasmus en die kerkhervormer Johannes Calvyn, werk die wapenfabricke van allerlei soort oral oortyd en van alkante gehoor die gedreun van die leërmobilisasies. Sal die komende oorlog een wees van nasie teen nasic, of sal dit een wees van beginsel teen beginsel-fasjisme teen kommunisme b.v.? In elk geval sal die Britse Ryk 'n soort tussen-posisie inneem, en met die oog op konsolidasie van dié posisie word ooreenkomste aan alle kante gesmee, maar veral ook saambinding van die dominiums nagestrecf.

Daarom word Súid-Afrika noll ook so aanhoudend bestook met imperiale wedvlugte, tentoonstellings, bioskoopvertonings en opwekkingsdienste, om die armsalige pedagogiese veldtog vanuit Skotland nou maar tersyde te laat. Die imperiale tentoonstelling van Johan- 
nesburg staan nog taamlik wel in die sentrum van die belangstelling, maar die reaksie teen sy eensydigheid skyn gelukkig ook aan te groei; net soos teen dié van die Poskantoor, wat 'n allerbelangrikste permanente imperiale agentskap in Suid-Afrika is.

Die provinsiale verkiesinge thet tot dus ver altans voldoende bewys dat nog 'n soliede blok anti-imperiale stemkrag in Suid-Afrika stand. gehou het en hierdic getuienis sal ongetwyfeld bevestig en versterk word deur die a.s. verdere provinsiale party-kongresse. Ook sulke niepolitieke volksbeweginge soos die voorbereiding vir die VoortrekkerEeufees toon duidelik 'n opnuut oplewende nasionale gecsdrif, wat ook alle kultuurbeweginge en in besonder dic literatuur en die $\Lambda$ frikaanse pers ten goede kom. Binnekort sal ook 'n kragtige rugsteun daarvoor gevestig word deur die publikasie van die Afrikanse psalmboek en selfs ook die Gesangebundel. En dis seker passend dat op hierdie tydstip 'n nasionale huldebetoning aan Totius as digter, Bybelvertaler en Psalmberymer op tou gesit is onder beskerming vaut die F.A.K.

Dic beweging vir Christelik-Nasionalc onderwys wen ook sigbaar aan krag en omvattendheid en daar is goeie rede om binnekort 'n nasionale onderwys-kongres ter bevordering hiervan te verwag. As ons hierby nog dink aan die kragtige aksie tot skepping van 'n permanente organisasie vir volkswelsyn en die stigting van Afrikaanse vakorganisasies op Christelik-Nasionale grondslag, dan kan veilig verklaar word dat die verbritsing-kampanje waarna bo verwys is, sy doel nie sal bereik nie, nieteenstaande die kragtige steun daaraan verskaf deur die voortdurende bloei van die goudmyne en die nogr heersende gees van politieke materialisme.

'n Minder strydwekkende gebied betree ons met 'n heenwysing na die voortdurende welvaart veral in Suid- $\Lambda$ frika, sover dit betref die handel en industrieë en in baie geringer mate die landbou. Behalwe die gewone tekens van voorspoed aan almal bekend, ook in hul gevaarlikheid, soos groeiende invoer en spoorwegverkeer ens., is daar ook gresonde verskynsels van industriële ontwikkeling op die gebied van die onedele metale en veral ten opsigte van yster en staal. Dis besonder verblydend dat Yskor nou eindelik winsgewend begin word, nieteenstaande sy baie thoë kapitalisasie.

Vir ons egter van meer belang is die feit dat die Ilollandse Afrikaner meer algemeen aandeel begin neem in handel en industrie, nie slegs as loontrekker nie, maar ook as ondernemer. In hierdie verband word veelal gebruik gemaak van die koöperatiewe organisasic- 
vorm wat in sy wese besonder geskik is om die samewerking te verseker van 'n groot aantal minder vermoëndes, soos juis die situasie is van die Afrikanerdom. Oral word verneem van die suksesvolle optrede van koöperatiewe handelsonderneminge van verskillende soort, asook van federasie van bestaandé koöperatiewe onderneminge. Daar is 'n groot toekoms in hierdie beweging, mits onder verstandige leiding ontwikkelend van onder af opwaarts.

Dat al hierdie voorspoed tot nog toe sterk eensydig is, blyk daaruit dat in stedelike gebiede werkgeleentheid nog steeds gebied word nietcenstaande die voortdurende instroming van plattelanders en uitlanders, terwyl die platteland nog nic in merkbare mate sy opnemingsvermoë van blanke arbeid versterk het nie. Die landbou bly nog die swak plek van ons ekonomic, nie alleen vanweë natuurlike oorsake nie, maar veral omdat die boerebevolking vir ons ingevoerde stelsel van boerdery nic algemeen toegerus en meer bepaald nie doeltreffend georganiseer en gefinansieer is nie. Ons beweeg wel in dic regte rigting, maar die staat wat die deurslag sou kan gee, werk mee om die verkeerde stelsel te bestendig deur voortdurend redmiddels toe te dien aan die slagoffers daarvan. Met die regte insig en die goeie wil sou dit betreklik maklik wees om ons boerdery weer op vaste voet te stel deur behoorlike organisasie van produksie en bemarking en krediet daarvoor. Dit sou natuurlik die genadeslag toedien aan die bocr se individualisme, maar daardic individualisme pas by 'n stelsel van selfversorgende bocrdery, nic by die bestaande stelsel van boerdery op groot skaal vir die mark en selfs vir die wêreldmark nic. Jin hoe gouer ons landboubevolking dit insien, des te beter. Anders sal die boerende Boer moet plek maak vir die beter boerende Uitlander, en daarmce sou die fondament van ons nasie-bestaan gewysig wees-Mag God dit verhoed! 